\title{
ECONOMIC COLLAPSE IN THE COUNTRYSIDE AND THE CONSEQUENT TRANSFORMATION OF CITY INTO FORTRESS IN LATE ANTIQUITY
}

By

\author{
ANDREW G. POULTER
}

General evaluations of historical or archaeological evidence, such as the title of this contribution, are unlikely to apply to all parts of the Roman Empire. Not that this is in any way surprising; the various economic factors, affecting different parts of the Empire, were a response to internal opportunities or problems and external threats, more vital to local interests than changes in policy formulated in Rome. Nor was the situation ever static; fluctuating levels of economic activity could radically change over time, affecting provinces to different degrees and even in very different ways. ${ }^{1}$ True, there were changes in government which did affect life in the provinces, but even these had both positive and negative impacts, depending upon local circumstances. ${ }^{2}$ There is no alternative but to see the empire, not as a single entity, but as the sum total of its constituent parts, not a collection of provinces all benefiting or suffering equally from developments emanating from the centre; no one region can be taken to exemplify general trends, even if the variety of research methods employed could be considered of equal validity. ${ }^{3}$

\footnotetext{
${ }^{1}$ Roman Britain is a case in point. Overall, it has been argued that there was a down-turn in interprovincial trade in the Late Roman period, especially in the north-western provinces, and that it can be detected in the British archaeological record; M. Fulford, 'Britain and the Roman Empire; the evidence for regional and long distance trade,' in R.F.J. Jones, ed., Roman Britain: Recent Trends (Sheffield 1991), 35-47. For reservations about the validity of extrapolation from a meagre database, see A. G. Poulter, Nicopolis ad Istrum, a Roman to early Byzantine City; the Glass and the Pottery (London 1999), 28-30. Even if economic links with other parts of the empire had declined, it is clear that Britain in the $4^{\text {th }}$ century experienced its greatest period of prosperity; cities were undiminished in size, unlike the small citadels, then typical of the formerly rich provinces of Gaul. No doubt one of the major causes of disruption on the continent had been the barbarian invasions of the $3^{\text {rd }}$ century, a catastrophe which had little effect on Britain, largely protected from invasion by the sea.

${ }^{2}$ See, for example, the changes in the status of towns and, consequently, changes in their economic status following the reforms of Diocletian; A.G. Poulter, 'The use and abuse of urbanism in the Danubian provinces during the Later Roman Empire', in J.Rich, ed., The City in Late Antiquity (London/ New York 1992), 99-135.

${ }^{3}$ For a review of regional surveys across the Roman Empire and their results, see W. Liebeschuetz in this volume. The research strategies adopted in different parts of the former Roman Empire differ markedly in their aims and their results, a factor complicated by variations in the quality of the methodology adopted. Despite rapid development in intensive survey over the last decade, even broad issues of significance are often less clear-cut than published conclusions so often imply.
} 
This may seem to represent an insurmountable obstacle in reconstructing the ever-changing pattern of economic conditions within the Roman Empire, but it does still allow - even encourages - the development of new ways to circumvent the problem, while still adhering to the principal aims of such an enquiry; identifying the processes at work and, if at all possible, discovering and quantifying the relative importance of human and possibly environmental factors. Self-evidently, the approach must be to construct regional strategies for archaeological research. These should provide the tools for tackling the key issues and identifying the effects of such changes on the inhabitants of the Empire. Although, of course, in archaeology, it is the effects which are recognised and from which the archaeologist backtracks to seek the most plausible cause. Simply embarking on field survey or excavation will not do. What is needed is the formulation of appropriate methods, not ones simply applied at random. ${ }^{4}$ All fieldwork is selective in its application, and involves making compromises for purely practical reasons: lack of time or financial support being the most common. There are other difficulties along the way. Inevitably, the execution of such an enquiry is never straightforward. Solving one problem raises another, which may have to be tackled with a different methodology. This secondary stage can confirm or undermine earlier conclusions, but, at least, shifting focus and approaching the research aims from a different direction will enrich the breadth of the enquiry, providing new archaeological data, consolidating advances already made. The following paper describes one such regional programme, its method of application, its change in direction, and its provisional, tentative conclusions.

The region under consideration is the lower Danube, and, in particular, the central part of the north Bulgaria plain which broadly extends from the Balkan mountains north to the banks of the Danube (Figure 1).

\section{From Roman city to early Byzantine Fortress}

The primary aim of the first programme of research (1985-1992) was to examine a Late Roman and early Byzantine city, to discover whether, in both its physical form and economic base, it survived as late as the $6^{\text {th }}$ century A.D. Nicopolis ad Istrum proved to be an ideal type-site for study. The Roman city lies in open country, largely unaffected by post-Roman activity, except where stone-robbing in the $18^{\text {th }}$ to early $19^{\text {th }}$ centuries has

\footnotetext{
${ }^{4}$ See D. Mattingly, 'Methods of collection, recording and quantification', in R. Francovich \& H. Paterson, eds., Extracting Meaning from ploughsoil assemblages (Oxford 2000), 5-15, especially p.5.
} 
systematically removed the walls of buildings, especially away from the agora where monumental structures, built from large masonry blocks, have survived remarkably well. Using the excavated remains and aerial photographs, which reveal the full extent of robbing, it proved possible to reconstruct the layout of the town as it existed in the Late Roman period, that is the $4^{\text {th }}$ to early $5^{\text {th }}$ century A.D. (Figure 2). ${ }^{5}$ However, the British excavations were carried out within the so-called 'annexe', a fortified enclosure of $5.6 \mathrm{ha}$, attached to the southern curtain-wall of the town and which, since it seemed to postdate the Roman city, was presumed to be the site of the Late Roman fortifications, commanding a strongly defensive position above the river Rositsa (Figure 3). As excavations proved, the Roman city was destroyed and abandoned towards the middle of the $5^{\text {th }}$ century, almost certainly following its sack by the Huns of Attila ${ }^{6}$. The construction of the subsequent fortifications occurred at some point during the latter half of the $5^{\text {th }}$ century, possibly as early as the reign of Marcian, and continued in use until its final destruction in the late $6^{\text {th }}$ century. There is no doubt but that the new fortification contained the early Byzantine city and, as anticipated, a geophysical survey of the interior, combined with selective excavation, provided a remarkably detailed reconstruction of a 'city' on the lower Danube in the age of Justinian (Figure 3). In physical appearance, the new foundation bore not the slightest resemblance to the regularly planned Roman city which it replaced. There was no regular network of paved streets. There were no public buildings surrounding a central agora, but there was a line of massive buildings with deep foundations of earth and stone, probably store-buildings, perhaps also serving as barracks, while the primary focus of the city was a Christian basilica, presumably the Episcopal basilica, prominently located at the highest point within the defences. There was a second, smaller church on the south-east side and some signs of buildings in the south-western quarter. Along the northern curtain, there were additional structures but no sign of intensive occupation. At the centre of the city, there was an open-ended pair of buildings, perhaps workshops, standing in isolation. Most surprising was the apparent absence of people; large areas of the interior remained

${ }^{5}$ A.G. Poulter, 'Town and country in Moesia Inferior', in Idem, ed., Ancient Bulgaria: the Proceedings of the International Conference on the Archaeology and Ancient History of Bulgaria, University of Nottingham (Nottingham 1983), 74-118.

${ }^{6}$ A.G. Poulter, Nicopolis ad Istrum, a Roman, Late Roman and early Byzantine city (London 1995), $34 \mathrm{f}$. 
apparently unoccupied. ${ }^{7}$ In essence, the early Byzantine city functioned as a military and ecclesiastical stronghold. Indeed, the best evidence for civilian settlement in the $6^{\text {th }}$ century comes from outside the new fortifications and from the ruins of the Roman city to the north.

The reconstruction of the early Byzantine city's physical appearance was not the only aim of the excavations. A central element in the research was the development of large-scale environmental and ceramic programmes, designed to explore the economic character of the city. The task proved the more successful because, beneath the early Byzantine levels, excavation uncovered substantial remains of buildings, dating to the earliest years after the city's foundation at the beginning of the second century, a suburban development with large town houses in the Severan period, and then an extensive extramural settlement of the $4^{\text {th }}$ century. ${ }^{8}$ Consequently, the analysis could follow the changing economic character of the city from its origins down to the early Byzantine period. From the very earliest years, the city rapidly developed a full Roman economy, exploiting its rich agricultural hinterland; cereals, notably bread wheat, barley and rye, as well as mutton, pork and beef reached the city in quantity. Local industries, for example fine ware pottery, supplied all local needs and represented a profitable export whereas imports were few and those attested early in the second century, such as lamps, were rapidly replaced by local products. The city would seem to have remained largely reliant upon its own resources, achieving its peak of prosperity under the Severi. As late as the 4th century, Nicopolis' agricultural economy would seem to have provided for most of its needs. The picture changes, however, after the abandonment of the Roman city and the construction of the early Byzantine defences. During the $6^{\text {th }}$ century there appears to have been much less reliance upon large-scale grain cultivation; the dominant crop was spring-sown millet, supplemented by pulses (bitter vetch, lentil and field bean). It seems that the city no longer relied upon the exploitation of its territory but developed 'market garden' cultivation, perhaps relying, to a significant degree, upon food grown within or immediately outside the fortifications. Imports of amphorae from the Aegean and North Africa increased and the limited quantities of fine ware in use were not local products, but were imported from Africa and Cyprus.

\footnotetext{
${ }^{7}$ In addition to resistivity surveying, a magnetometer survey of blank areas, notably on the northeastern part of the site, failed to discover other structures. See P. Strange in Poulter 1995, op.cit. (n.6), 259-262.

${ }^{8}$ The ceramic report has been published by R.K. Falkner and the glass by J.D. Shepherd in Poulter 1999, op.cit. (n 1). This also contains a discussion of the changes in the economic character of the city.
} 
It would be fair to suppose that the dramatic change in the economy of the city was connected with the city's new appearance and, no doubt too, with its new function. But without comparable research available from other cities across the Eastern Roman Empire, it remains uncertain whether Nicopolis represented a new kind of city, typical of the early Byzantine period, perhaps a product of imperial policy, or whether its condition in the $6^{\text {th }}$ century was precipitated by an economic collapse on the Lower Danube and was a regional phenomenon, not shared by other parts of the empire. ${ }^{9}$ There is reason to believe that other early Byzantine cities in the region, notably Justiniana Prima (Tsarichin-Grad) and Tropaeum Traiani, shared similar features with Nicopolis and none bore more than a superficial similarity with urban centres of the early Roman Empire. ${ }^{10}$ A new starting point for attempting to understand what happened at Nicopolis is the countryside, the city's rich agricultural territory, clearly the basis of its wealth until the early $5^{\text {th }}$ century and from which, in the early Byzantine period, it would seem to have been inexplicably divorced.

The second archaeological programme was created to explore the economic development of Nicopolis' hinterland from the $4^{\text {th }}$ to $6^{\text {th }}$ centuries, particularly examining agricultural productivity and practice, data which could be compared with the environmental evidence from the city itself. This new direction comprised two elements. One was a large-scale excavation of a fortified settlement to the west of the ancient city. The other was fieldsurvey, directed towards establishing whether there had been a significant dislocation in the settlement pattern which could account for the collapse of the urban economy. The method was, not to examine the landscape as such, but to concentrate upon the upper levels in the settlement hierarchy, especially the villa estates. As with all cities of the Roman Empire, the support of urban government and the maintenance of urban structures were in the hands of the local elite, whose wealth was derived from the agricultural exploitation of the city's territory. In the case of Nicopolis, the urban plan suggests that, by the 4th century, this urban aristocracy included only a small group of wealthy families; away from the administrative centre of the city, outer insulae were occupied by large town houses, perhaps only

\footnotetext{
${ }^{9}$ For a survey of our current knowledge of Late Roman cities see L. Lavan, 'The late-antique city: a bibliographical essay,' Recent Research in Late-antique Urbanism. Journal of Roman Archaeology Supplementary Series 42 (Portsmouth RI 2001), 9-26.

10 .A. G. Poulter, 'The use and abuse of urbanism in the Danubian provinces during the Later Roman Empire', in J.Rich, ed., The city in Late Antiquity (London/ New York 1992), 99-135.
} 
some twenty or so in total (Figure 2). ${ }^{11}$ Any disruption to the economic position of the urban elite, reflected in an abandonment of villas in its territory, would inevitably impact upon the city of Nicopolis and would threaten its survival. If, on the contrary, survey demonstrated no disturbance to the social structure of landholding occurred even as late as the $6^{\text {th }}$ century and the excavations found no evidence for radical change in the agricultural economy, the case for a regional explanation for the decline of the Late Roman city would then be an improbable explanation.

\section{The fort of Dichin: a garrison in the countryside}

The 'type site' chosen for excavation, was a fortified settlement on the south bank of the river Rositsa, close to the modern village of Dichin and $10 \mathrm{~km}$ west of the Nicopolis. ${ }^{12}$ Excavations commenced in 1996 and were completed with a final season in 2001. Currently, post-excavation is under way in preparation for final publication and the presentation of the combined results of the work at Dichin and Nicopolis at an international symposium will be held at the British Academy in May 2003.

Just as at Nicopolis, the walls of the buildings of this Late Roman site had been robbed during the late $18^{\text {th }}$ or early $19^{\text {th }}$ century and structures were visible on the surface as partly silted robber-trenches. Consequently, by carrying out a detailed survey of the hill-top it was possible to produce a general plan of the site as it must have appeared during the latest period of occupation (Figure 4). Fortunately, excavation established that the general state of preservation within buildings was excellent, even where the walls had been completely removed. The intention had been to excavate an ordinary village, dating to the $4^{\text {th }}$ to $6^{\text {th }}$ century A.D. Although the site

\footnotetext{
"For discussion of the urban plan, see A.G. Poulter, 'Nicopolis ad Istrum: the Anatomy of a GraecoRoman City', in H.-J. Schalles, H. von Hesberg \& P. Zanker, eds., Die Römische Stadt im 2. Jahrhundert $n$. Chr. Der Funktionswandel des öffentichen Raumes, Kolloquium in Xanten vom 2. bis 4. Mai 1990, veranstaltet durch das Archäologische Park, das Regionalmuseum Xanten, das Archäologische Institut der Universität zu Köln und die Bayerische Akademie der Wissenschaften Kommission zur Erforschung des antiken Städtewesens (Köln/ Bonn 1992), 69-86. Of course, it is quite possible that some members of the elite lived on their estates and did not own houses in the town. Even so, it is notable that hypocausts in the surrounding villas are rarely found in the main residence. This suggests, given the harsh cold winters in Bulgaria, that many of the villa owners in the winter moved to the city, where hypocaust heating was provided for public as well as private buildings.

${ }^{12}$ A.G. Poulter, 'The transition to Late Antiquity on the lower Danube: an interim report', The Antiquaries Journal 79 (1999), 145-185. See also A.G. Poulter, 'The Roman to Byzantine transition in the Balkans: preliminary results on Nicopolis and its hinterland,' Journal of Roman Archaeology 13 (1999), 347 - 358.
} 
proved to be of the right date, it was soon clear that this was no ordinary civilian settlement. Its finely built defences included massive, rectangular and circular towers along the main curtain-wall, strengthened by a secondary outwork (proteichisma), an unusual provision normally restricted to large and important urban centres. Moreover, the regular arrangement of the buildings and then the discovery of weapons and shields proved that Dichin had been a fort, containing a military garrison, at least during its first period of occupation which commenced soon after A.D. 400 and which ended in destruction during the third quarter of the $5^{\text {th }}$ century. There followed a short period of abandonment during which dogs scavenged amongst the ruins and gnawed at the bones of corpses. Following an extensive levelling of the period 1 buildings, the fort was reoccupied and remained in use until a second destruction, towards the end of the $6^{\text {th }}$ century, after which the site was never reoccupied. The first of these two periods is of particular relevance to the theme of this paper. Although military finds prove that the fortification had been occupied by soldiers, the period 1 destruction level also contained more than 30 scythes, a plough and other agricultural tools which suggests that the occupants were also engaged in agriculture. The identity of these soldier/farmers is of singular interest. In the case of the fort of Iatrus (Krivina) on the Danube (Figure 1), it has been argued that, by the late $4^{\text {th }}$ century, it was occupied by an irregular garrison of Gothic troops. ${ }^{13}$ At the time Dichin was destroyed, in the reign of Leo (457-474) or shortly thereafter, the lower Danube was only nominally under Byzantine control and a Gothic garrison of foederati, owing allegiance to a Gothic overlord, is more likely to have been based there than regular Roman troops. ${ }^{14}$ Whether there was already a Gothic garrison there from the outset, that is c. 400 , is an intriguing question. At Iatrus, the Roman military character of the fort had existed during the first half of the $4^{\text {th }}$ century and was only abandoned after 350. At Dichin the layout of the fort's internal buildings, with only a passing concession to some regularity in planning, and their crude construction is evident from the start. There were changes in detail, but no major reorganisation of the internal plan, at least until after the end of period $1 .^{15}$

${ }^{13} \mathrm{G}$ von Bulow in Iatrus-Krivina, spätantike Befestung und fruhmittelalterliche Siedlung an der unteren Donau (Berlin 1995), 29-53. Notable, is the appearance of store-buildings and 'granaries' of an unusual construction but exactly paralleled in finds from Dichin; see following, note 16.

${ }^{14}$ For Gothic suzerainty over the Lower Danube, see below, p.257-259.

${ }^{15}$ A large, imposing building, partly built from mortared masonry, occupies a prominent position at the end of the main internal road, leading west from the main gate at Dichin. Its location corresponds well with the site of the principia at Iatrus. However, whatever the original function envisaged for this partly mortar bonded building, its east end was completed with stone bonded with earth, and it was 
With no obvious break in the character of occupation, it seems likely that the fort contained an irregular force from the beginning.

Another important problem is to discover what role the fort performed and how its presence affected the countryside in which it lay. The existence of such a fort on the south bank of the river is totally unexpected; Dichin does not seem to have occupied a strategic position: the closest Roman road passes beyond the river to the north as it heads west from the city of Nicopolis. The fort does, however, command a broad sweep of land along the middle reaches of the Rositsa, amongst the most fertile parts of Nicopolis' extensive territory. In each of the excavation areas, the destruction deposits, which marked the end of period 1, contained substantial quantities of cereals in granaries with raised floors. These were intended for the storage of substantial amounts of grain and some imported goods, including amphorae and small quantities of fine ware pottery (Figure 5). As a stores-base, acting as a collection point for agricultural supplies, food could have been shipped down the Rositsa and then north to the Danube where the fort of Iatrus was equipped with similar storage facilities. ${ }^{16}$ This fort could have performed a similar role to Dichin, acting as a supply base, collecting produce from the lower Yantra valley. From here, agricultural goods could have been transferred to larger vessels for delivery to military garrisons along the Danubian frontier. Preliminary analysis of the carbonized grain from the period 1 destruction level included a wide variety of produce; emmer wheat, oats and barley as well as millet, rye, Celtic beans, bitter vetch, lentils and pea. Mutton and pork were eaten and, as at Nicopolis, wild animals were hunted (including deer, boar, hare and wild bovines), but apparently not in sufficient quantities to suggest that they formed a significant element in the inhabitants' diet. ${ }^{17}$ As yet, from the wide range of no doubt locally grown foodstuffs identified, there is no sign at Dichin that there had been a major change in the types of agricultural produce being grown since the $4^{\text {th }}$ century. Until further analysis of the finds from the second destruction level can be carried out, it is not yet possible to say

used from the beginning as a granary. There is no reason to believe that Dichin ever possessed a late Roman headquarters building, nor separate residence for the commander of the garrison.

${ }^{16}$ For a reinterpretation of some buildings at Iatrus as granaries, of identical build to those at Dichin, see A.G. Poulter, 'Gradishte near Dichin: a new Late Roman fortress on the lower Danube', in G. von Bülow \& A. Milcheva, eds., Der Limes an der unteren Donau von Diokletian bis Heraklios (Sofia 1999), $207-227$.

${ }^{17}$ On the archaeobotanical results see P. Grinter and A. Avery on the archaeozoological analysis; Poulter 1999, op.cit. (n.1), $176 \mathrm{f}$. 
whether there was any difference between agricultural production in the late $5^{\text {th }}$ and the late $6^{\text {th }}$ century.

\section{The rural landscape; villas and villages}

Since the 1980 's, as part of a national Bulgarian initiative for mapping all archaeological sites in the country, systematic survey has been conducted within Veliko Turnovo county, an area of c. 2000 square kilometres (Figure 1). To date, 268 Roman and Late Roman sites have been registered. ${ }^{18}$ Impressive though the total is, because the work was not carried out by extensive survey, it is probable that most of the sites identified belong to the upper levels in the settlement hierarchy, that is villas or villages, whereas the humbler hamlets or isolated farmsteads are likely to have escaped detection. Our research, over the first three field seasons (1999 - 2001), on 16 of these sites suggests that this is indeed the case. ${ }^{19}$ However, as described above, the survey concentrates on villa sites, with the aim of discovering whether the wealthy land-owning class survived into the early Byzantine period. So it has proved acceptable to limit our attention to the catalogue of identified sites. That is not to say that an intensive survey, identifying all types of settlement, would not be worthwhile. Such a programme would provide a fuller understanding of all settlement types and may identify broad changes over time, but that would have required a very different programme. The sitespecific surveys, directed towards the villas, was sufficient for our more restricted purpose. ${ }^{20}$ In practice, the survey included two distinct aspects. Clearly, it would be impossible to attempt examining all, or even a large proportion, of the registered settlements. The number that can be surveyed over a five-year cycle, the limit of our programme, is unlikely to exceed 30 in total. ${ }^{21}$ Consequently, the method adopted was to select one group of sites from as widely separate parts of the region as possible, with the hope that this might reveal any variations in the character of settlement and, on the other hand, to concentrate on one restricted area, to provide more complete

\footnotetext{
${ }^{18}$ The research has been carried out primarily by Mr Ivan Tsurov of the Historical Museum, Veliko Turnovo.

${ }^{19}$ All but one of the sites so far surveyed can be safely identified as villas. The exception is probably an industrial centre, close to the banks of the Yantra river.

${ }^{20}$ Using existing sites also had the advantage that the invaluable knowledge of $\mathrm{Mr}$ Ivan Tsurov, the regional field officer who had identified them, ensured that these major settlements could be located immediately. For further comment on the limitations of the approach we adopted see the conclusion.

${ }^{21}$ A complication is agricultural land-use. Even for the smaller sites, not all fields are available for survey in the same season. This regularly involved returning to sites in subsequent years in order to complete the survey.
} 
coverage. The Rositsa valley was the obvious choice for intensive treatment, partly because it had proved unusually productive in sites, but also because the results could be directly compared with the excavations underway at Dichin.

A new method was developed to undertake this programme of sitespecific survey. The objectives were ambitious; to discover what kind of site was being investigated (whether temple, villa or village), to date its period of occupation, and to define its full extent within the immediate landscape, including the distribution and number of other associated buildings within a $1 \mathrm{~km}$ radius of the primary centre. For a rich agricultural region which has been intensively farmed, this might seem an unrealistic expectation. However, during a survey, combining intensive pickup and geophysics in an equally rich agricultural region in north-eastern Greece (the Pieria), it had proved possible to discover, explore and date a previously unknown, major early Byzantine fortification. ${ }^{22}$ Although the method adopted in Greece relied heavily upon total pickup within transects, it was clear that building materials and even pottery had moved hardly at all since Antiquity and had not been dispersed, despite recent deep ploughing and intensive cultivation over the last two thousand years. It was also a surprise to discover that 'click-surveys', recording the spread of surface material, were remarkably successful in identifying quite subtle changes in the density of surface finds.

In Bulgaria, the major improvement in methodology involved the adaptation of the standard 'click survey,' using units of $5 \times 25 \mathrm{~m}$, to quantify the density of all surface finds (building stone, brick/tile and pottery) across the landscape, plotting out the results using a GIS programme. This proved remarkably successful in surveying extensive tracts of land around sites, regularly across fields up to one kilometre in length, isolating 'hot spots', where surface debris of Roman date was found. ${ }^{23}$. Resistivity surveys established that the concentrations of finds directly overlay buildings. Occasionally, the outline of buildings and associated courtyards were still visible on the freshly ploughed fields. From the pottery, the 'hot spots' could be confidently identified as Roman and the examination of the material on the surface can be used to differentiate between structures of different construction and status, as in the use of mortared or dry-stone walls, the use or absence of brick and tile. Only when all buildings have been identified,

\footnotetext{
${ }^{22}$ Poulter, A G. ,'Field survey at Louloudies: a new late Roman fortification in Pieria', Annual of the British School at Athens 9 (1998), 463-511.

${ }^{23}$ The detailed description of the methodology is currently being written up for publication. It will be offered to The Journal of Field Archaeology.
} 
was pottery picked up, never at random from the site as a whole, but always from individual buildings or complexes of associated structures, located by the click survey. This allows each building to be treated as a distinct element in the landscape; its building type ascertained and estimates made as to function and date. The close study and quantification of pottery was possible because the region's ceramic sequence of local fine and course wares has been established by the excavations at Nicopolis. ${ }^{24}$

One unexpected result of the surveys carried out so far is that none of the settlements have proved to be villages: all but one of the sites (a small industrial centre on the banks of the Yanta) were villas. This is surprising since villages are quite commonly attested in Roman inscriptions in Lower Moesia and Thrace, three of which are known to have existed within Nicopolis' territory. ${ }^{25}$

Of particular interest is the evidence for the social organisation of the villa estates. For villas in the northern half of the city's territory, estates were much more than simply isolated farmsteads with ancillary agricultural buildings. At Mramora, near the village of Gorna Lipnitsa, $20 \mathrm{~km}$ north-west of Nicopolis, a resistivity survey, carried out over the greatest surface concentration of fine-ware pottery and building materials, located the clear outline of a Roman villa, a peristyle court, surrounded by rooms on all four sides, with an ancillary range of buildings running west/east either side of a large central courtyard (Figures 6 and 7). A very large, circular anomaly, $30 \mathrm{~m}$ in diameter, to the south-east, may well have been a funerary monument. However, the high concentrations of brick, stone and pottery in the large field to the west of the main villa indicated the presence of other buildings, one of which can be confidently identified as the building complex, seen as a surface feature, 25 years ago. (Figure 7) The outline of another compound was still visible during survey in 2000. All the buildings produced fine and course ware in similar proportions to that recovered during pick-up over the site of the main villa, suggesting that each of these newly identified structures were houses, not outbuildings. Like the main villa, all produced examples of the earliest pottery found at Nicopolis, which must mean that they were in use from the very early $2^{\text {nd }}$ century. Moreover, a line of Roman tumuli, almost obliterated by ploughing, was noted just

\footnotetext{
${ }^{24}$ Poulter 1999, op. cit (n.1).

${ }^{25}$ A.G. Poulter, 'Rural communities (vici and komai) and their role in the organization of the limes of Moesia Inferior,' in W.S. Hanson \& L.J.F. Keppie, eds., Roman Frontier Studies 1979: papers presented to the 12 th international congress of Roman frontier studies. B.A.R. International Series 71 (Oxford 1980) Part III, 729-744.
} 
beyond the most southerly extent of this settlement. No doubt it was the cemetery used by the community which lived there in the $2^{\text {nd }}$ to perhaps early $4^{\text {th }}$ century A.D. To the east of the villa and to the south, further buildings were identified. Here, for the first time in 2001, brick, stone and pottery were recorded separately and not together (as had been the case in the western half of the site, surveying in 2000). This meant that it was possible to pick out, apart from the villa site itself, two more 'high status' buildings, using tile/brick, possibly one of which was a bath-building, as well as simple outbuildings made of limestone and earth walls, and probably thatched, with virtually no associated pottery.

Mramora would seem to have not just been a villa but to have had an extensive settlement of houses, at least two of which had south-facing courtyards, no doubt for private stock and gardens, presumably representing the homes of estate workers. Although $180 \mathrm{~kg}$. of pottery from this site has been recorded and quantified, the full analysis has still to be carried out. Even so, it is already apparent that neither the villa, nor the associated settlement, survived beyond the end of the $4^{\text {th }}$ century.

Not all villas had associated communities. Along the middle reaches of the Rositsa, in the sub-region where an attempt has been made to survey as many sites as possible, villas have been found on either side of the river valley, regularly spaced, about $2.5 \mathrm{~km}$ apart. Four have proved to be villas but, in each case, survey has found very few outbuildings, none of which appear to have been used for domestic accommodation. Lesicheri I is a good example. Here, a well-know landmark is a standing Roman column and a very large tumulus, associated with a temple of the Thracian horseman. Although, before survey, it seemed that this may have been a shrine and associated village, this proved not to be the case. The main villa, visible as a surface concentration, was examined by geophysics. It turned out to have been a particularly clear example of the peristyle type with a small courtyard which contained an ancillary building. But the only other structures in the vicinity were three outbuildings, built of limestone blocks and bonded with earth, none of which produced much pottery.

The landscape, even at the upper levels within the settlement hierarchy, would seem to differ in character from one part of the city's territory to another. The Rositsa valley appears to be an ordered landscape, with its regularly spaced villas, consisting of single villa farmsteads, each with similar sized parcels of land running from the watershed at the top of the valley down to the river. So regular would seem to be the pattern that it 
suggests that it was imposed, perhaps by a redistribution of land when the city was first founded. ${ }^{26}$ Further north, as at Mramora, the pattern is different and the more widely spaced, large estates with dependant villages, which may prove to be the norm, points to a very different economic and social origin. Although Roman and Greek names dominate in the inscriptions in the central and western part of the city's territory, further away, towards the periphery of Nicopolis' lands, native names are in the majority. ${ }^{27}$ Just possibly, the larger, more remote farms were occupied by native Thracians and the associated communities are, not just estate workers, but communities which had been dependant upon the local landowners in the pre-Roman period and who maintained their loyalty - or their dependence - into the $2^{\text {nd }}$ century A.D.

The absence, so far, of any villages (vici and komai), known to have existed around Nicopolis, is still puzzling, unless the nucleus of houses, such as that around the villa at Mramora, is the kind of settlement to which the inscriptions refer. Villages on villa estates are attested epigraphically in North Africa and, on the Lower Danube, some vici are named after individuals, perhaps the owners of the land upon which the villages were established. ${ }^{28}$ What is certainly a consistent feature of all the sites so far surveyed is that none have produced pottery later than the $4^{\text {th }}$ century; and none were therefore occupied when the fort at Dichin was built. ${ }^{29}$

\section{The disappearance of the villa economy and its impact on the city}

Much more needs to be learnt about the settlement pattern and the changes it underwent in the Late Roman period. What happened to the smaller communities and isolated native farmsteads remains unknown and the sitespecific survey programme, though useful for the purpose it was designed for, can provide no answer to this important question. During the course of the $5^{\text {th }}$ and $6^{\text {th }}$ centuries, numerous hill-top sites, defended by primitive but

\footnotetext{
${ }^{26}$ The early population of the city is dominated by immigrants, primarily Greeks from Asia Minor. Also, the remarkably rapid development of a full Roman agricultural and industrial economy within the first few years after the city was created, along with the almost total absence of native Thracian pottery, suggests that Nicopolis was largely occupied by new settlers, perhaps attracted by the offer of free land; Poulter 1995, op.cit. (n.6), 22-25.

${ }^{27}$ Poulter 1992, op.cit. (n.11), 81 and fig. 53.

${ }^{28}$ For example, the vicus Celeris, vicus Secundini, vicus Quintionis, vicus Narcissiani, all in the central Dobrogea, close to the Black Sea coast. See above, Poulter 1980, op.cit (n.25) and A.G. Poulter, 'Townships and villages,' in J. Wacher, ed., The Roman World (London 1987), 388-411.

${ }^{29}$ The distinctive grey wares, dominate the assemblage from Dichin. The fine red wares were no longer available. On the implications for the economy and further discussion on the date of Dichin's foundation, see following, p.258-259.
} 
stout defences, were in use, no doubt to protect the native population, perhaps also newcomers. ${ }^{30}$ Some, like Golemanovo Kale, to the west of Nicopolis, appear to have been permanent settlements and the neighbouring site of Sardovsko Kale, from its regular arrangement of identical 'houses', might have contained a garrison. ${ }^{31}$ Others may have been temporary refuges for agricultural workers who continued to live on lowland sites. Until intensive survey has proved whether or not there was a total abandonment of lowland settlements, the wider picture remains incomplete.

What is, however, becoming increasingly clear, not just for the lands around Nicopolis but for the whole of the north Bulgarian Plain, is that there was a general abandonment of Roman villas during the Late Roman Period. Quite precisely when remains to be determined but a date in the last quarter of the century would fit with the available evidence. ${ }^{32}$ The period provides an obvious context. The arrival of the Gothic Tervingi, settled in Thrace by Valens in 376, may not have involved an immediate and general change in the character of land-holding. But the subsequent rebellion and the turmoil which followed the destruction of the Roman army and the emperor's death in the Battle of Adrianople, must have resulted in widespread disruption. Still more seriously, in the long term, the treaty, forced on Theodosius in 382 , involved the granting of Roman land to the Goths and left them in effective control over their own affairs. ${ }^{33}$ Horrified by the consequences of the Gothic Revolt, the citizens of Nicopolis probably resisted, taking up arms against Goths settled in their territory, incurring thereby Theodosius' anger. ${ }^{34}$ Resistance proved futile and the villas were abandoned. No doubt those who could do so migrated south, leaving those who did not impoverished, without the financial means to sustain the city's administration or maintain civic amenities. With the demise of the landowning class, the city could not survive for long. The final catastrophe came with the arrival of the Huns. After the restoration of imperial authority, which was not fully realised until late in the $5^{\text {th }}$ century, there was no attempt to revive the villa system. Deprived of its agricultural base, the city, in its traditional form, was dead. Consequently, the 'polis' of the $6^{\text {th }}$ century had to

\footnotetext{
${ }^{30}$ Poulter 1983, op.cit. (n.5), 97-100.

${ }^{31}$ See S. Uenze, Die spatantiken Befestigungen von Sadovec (Bulgarien) (Munich 1992).

${ }^{32}$ Coin finds from excavated villa sites in the north Bulgarian plain suggest that villas do not continue into the $5^{\text {th }}$ but did survive into the later $4^{\text {th }}$ century; V. Dinchev, Rimskite vili vuv dneshnata bulgarska teritoriya,(Sofia 1997).

${ }^{33}$ P.J. Heather, Goths and Romans 332-489 (Oxford 1991), 158-165.

${ }^{34}$ Poulter 1995, op.cit. (n.6), 16.
} 
be maintained by imperial authority and was no longer dependant upon its former territory.

As argued above, the fort of Dichin was established c. 400 , possibly from the outset garrisoned by irregular troops, perhaps Goths, who farmed the surrounding lands. It acted as a collection point for agricultural produce, at least down to its first destruction in the late $5^{\text {th }}$ century. Very soon after the disappearance of the villas, the valley of the Rositsa had come under direct military control. The situation elsewhere on the lower Danube is less clear but other forts existed in the interior and may well have played a similar role. To the west, at Montana (Mihailovgrad), a strongly fortified hill-top site continued to be used during the $5^{\text {th }}$ and $6^{\text {th }}$ centuries, after the abandonment of large villas which existed in the vicinity down to the end of the $4^{\text {th }}$ century. Like Dichin, it had a proteichisma to protect its single gate and granaries, as well as barracks. ${ }^{35}$ To the east, there is another fort at Madara, notable for its associated cave, used to store grain in massive dolia. ${ }^{36}$ The city, for three hundred years, had played its role as a market and distribution centre for agricultural products, supplying in kind or in coin the frontier garrisons. It would seem likely that the collapse of the villa economy - and with it the demise of the city - precipitated the militarisation of the countryside and the new role for forts like Dichin, ensuring the supply of the Danubian frontier. The change is also reflected clearly in the pottery. At Dichin none of the fine, high quality red wares, so popular in the $2^{\text {nd }}$ to $3^{\text {rd }}$ centuries at Nicopolis and on villa sites, has been found. There is no reason to suppose that the occupants of the fort would not have appreciated such tableware if it was still available. Production must have ceased because the market for such luxury items no longer existed. Instead, the functional grey wares dominate the fort's assemblage, the only exception being rare fine ware imports from abroad.

No explanation is more than an association of contemporary, or near contemporary events, and the reasonable, if improvable, presumption that the one leads inevitably to the other. New evidence may revise this sequence of events or suggest other interpretations. But, for the moment, a link between the collapse of the villa system, the radical new role of the city as an

${ }^{35}$ L. Ognenova-Marinova, et al., Montana (Sofia 1987). The regularly spaced bases, recorded by the excavator, G. Aleksandrov, in several of the rooms, represent the supports for raised wooden floors of granaries as described above for Dichin.

${ }^{36}$ I. Velkov, 'Razkopki v Madara (1924-1928), Sbornik Madara, Razkopki I proouchvaniya, Sofia 1934, 123-127; Ts. Dremsizova and V. Antonova, 'Sklad na hrani v Madara,' Arheologiya V!/4, (1964), 30-36. 
imperial, ecclesiastical and military centre, and the take-over of the countryside by military garrisons, involved in agriculture themselves, as well, no doubt, as requisitioning supplies, seems credible. The fact that, as late as the last quarter of the $5^{\text {th }}$ century, the countryside was still capable of producing substantial quantities of grain does not suggest that there had been any environmental deterioration which could have played a part in the collapse of the city. Given that this dramatic change would seem to have occurred at the end of the $4^{\text {th }}$ century, the arrival of Gothic settlers from 376 and the subsequent collapse of Roman military control seems a plausible reason why this train of events was set in motion. ${ }^{37}$ If so, the fate of the lower Danube was very much the outcome of its own economic circumstances when combined with exceptional historical events, peculiar to the region and not shared by other parts of the Roman Empire. Although the title of this paper provides (at the moment) a plausible explanation for the economic disaster which befell the Lower Danube c. 400, it does not follow that other provinces followed a similar course.

The search must continue to reconstruct the economic situation in other provinces before we can adequately assess the results and consider what general deductions can be made. Even if sufficient information is obtained, this could prove a difficult task. No overriding conclusions may adequately describe the complexity of regional trends which account for the rise and decline of very different economies co-existing within the Roman Empire.

Nottingham, January 2002

\footnotetext{
${ }^{37}$ More Gothic immigants may well have arrived on the Lower Danube after Theodosius' death as early as the 420's; Heather 1991, op.cit. (n.33), $261 \mathrm{f}$.
} 
Figure 1. The survey region

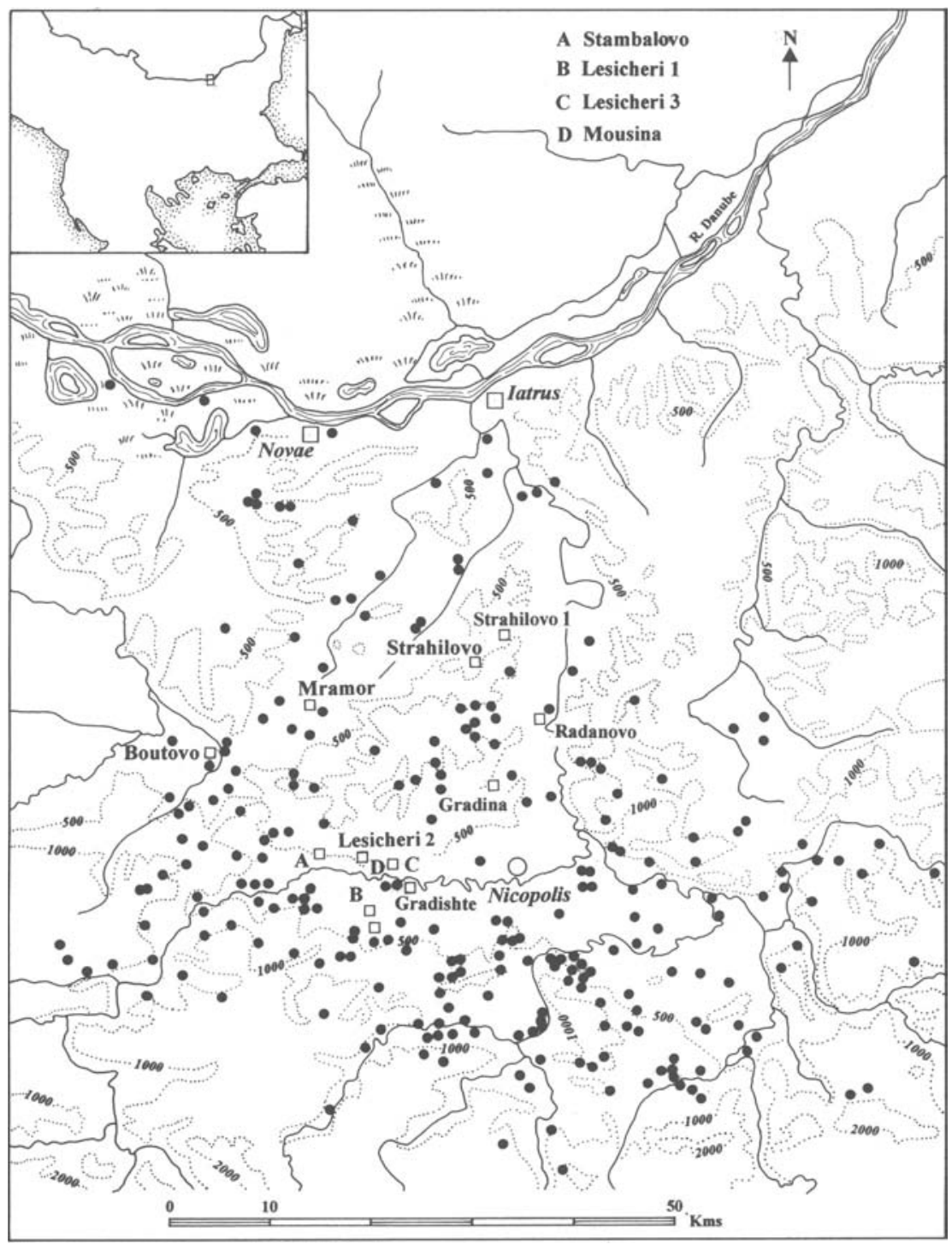


Figure 2. The Roman city of Nicopolis

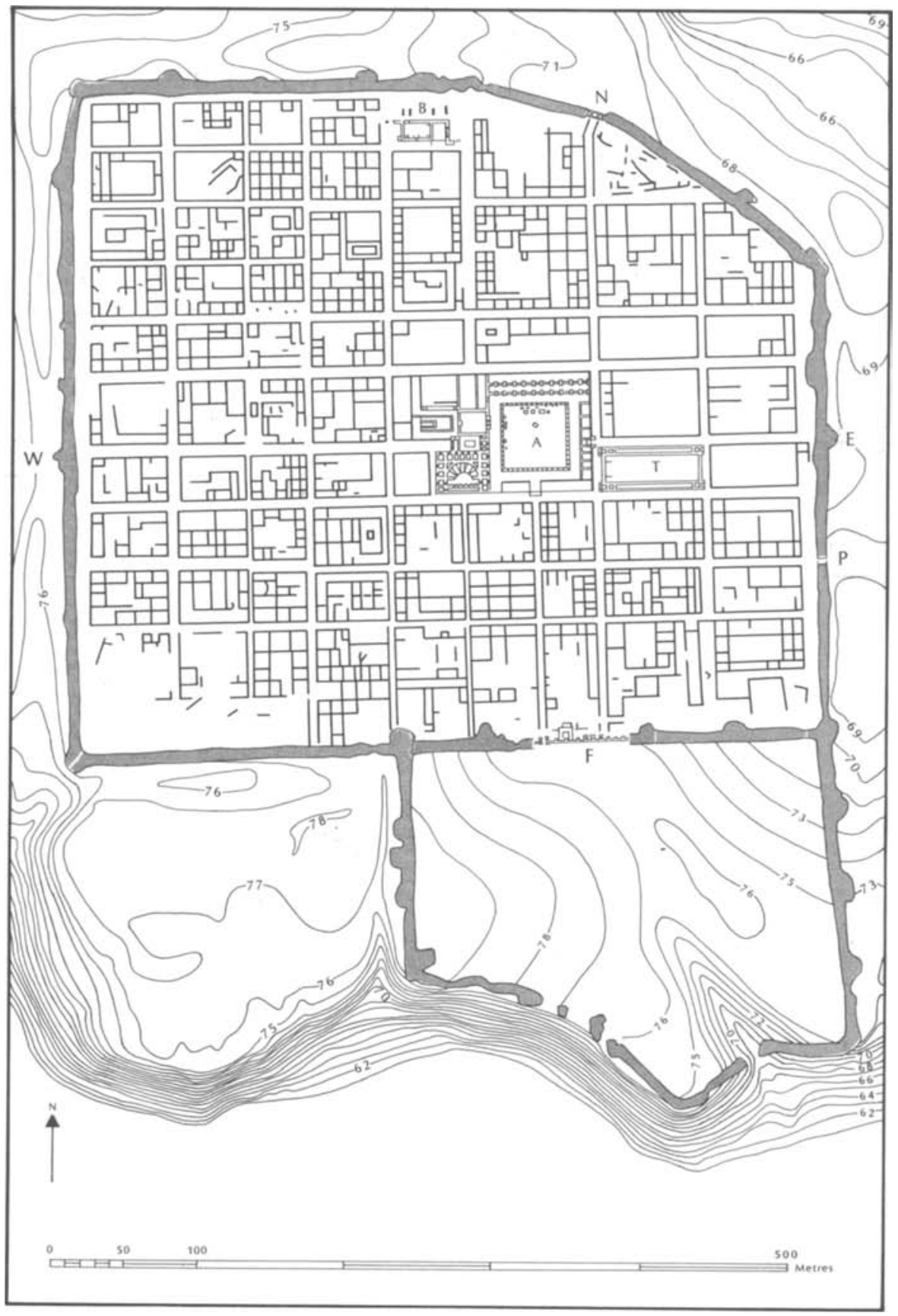


Figure 3. The early Byzantine city, c. 500

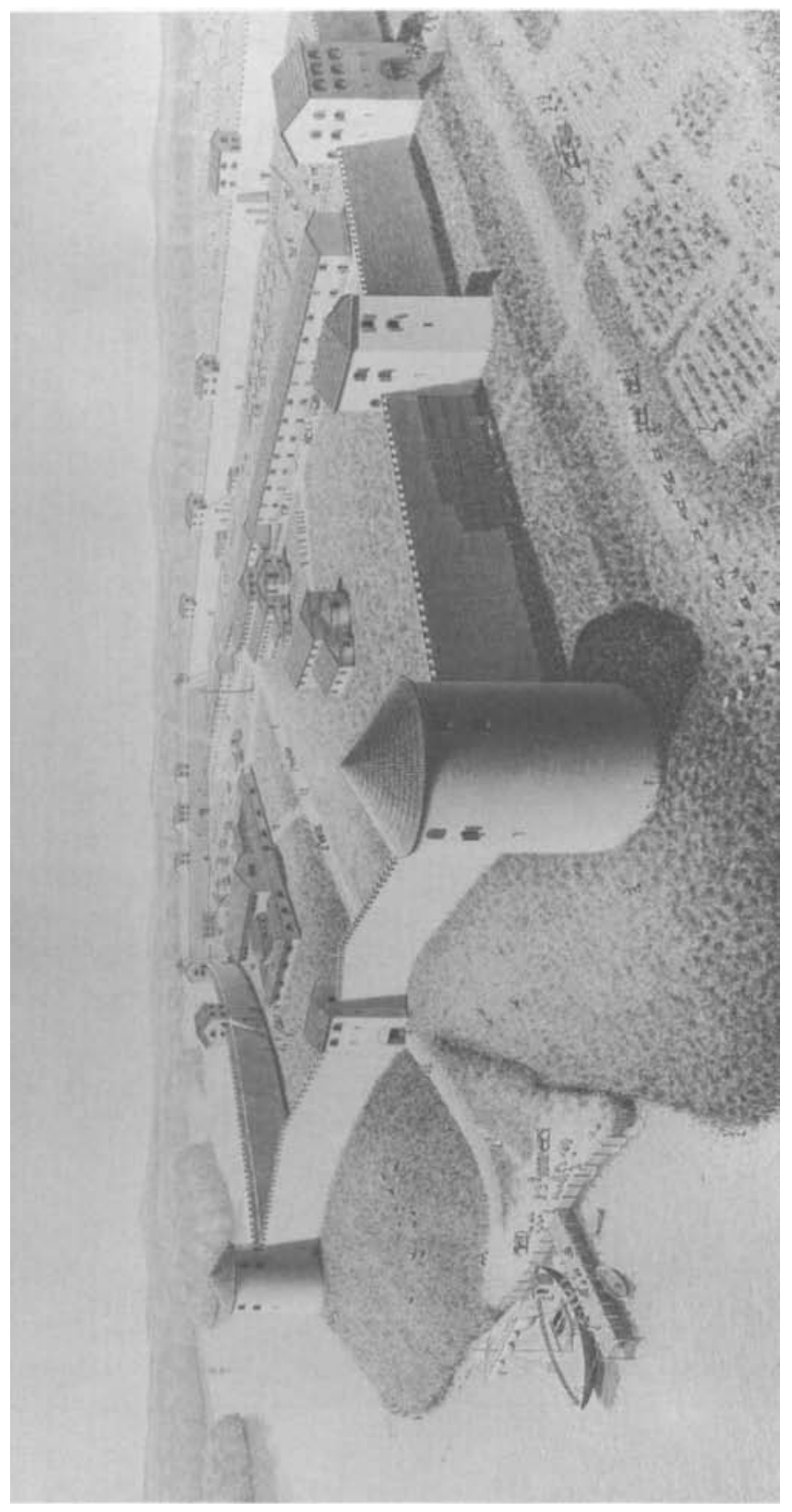


Figure 4. The fort of Dichin

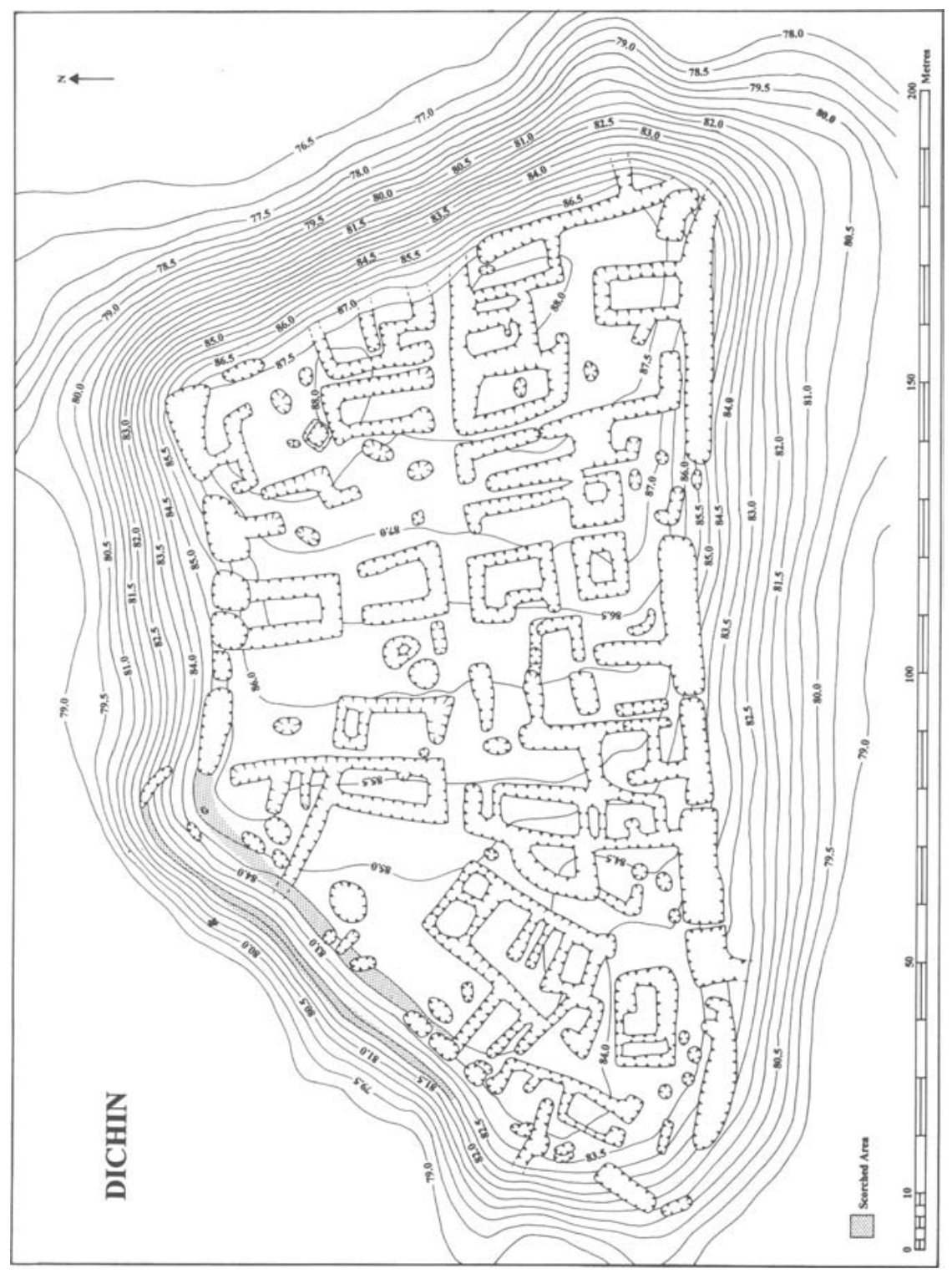


Figure 5. Reconstruction of a granary c. 475, Dichin

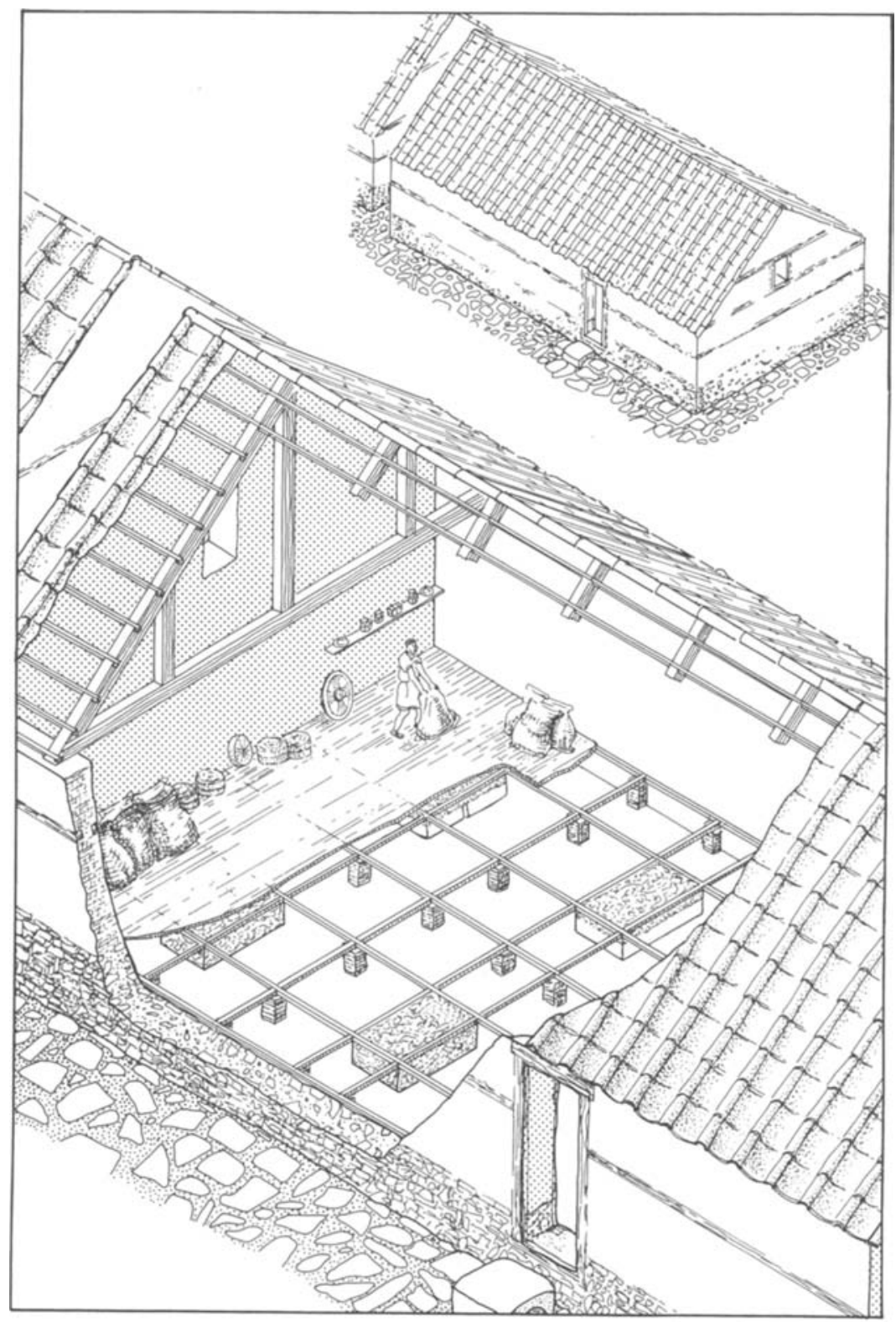


Figure 6. The field-survey at Mramora

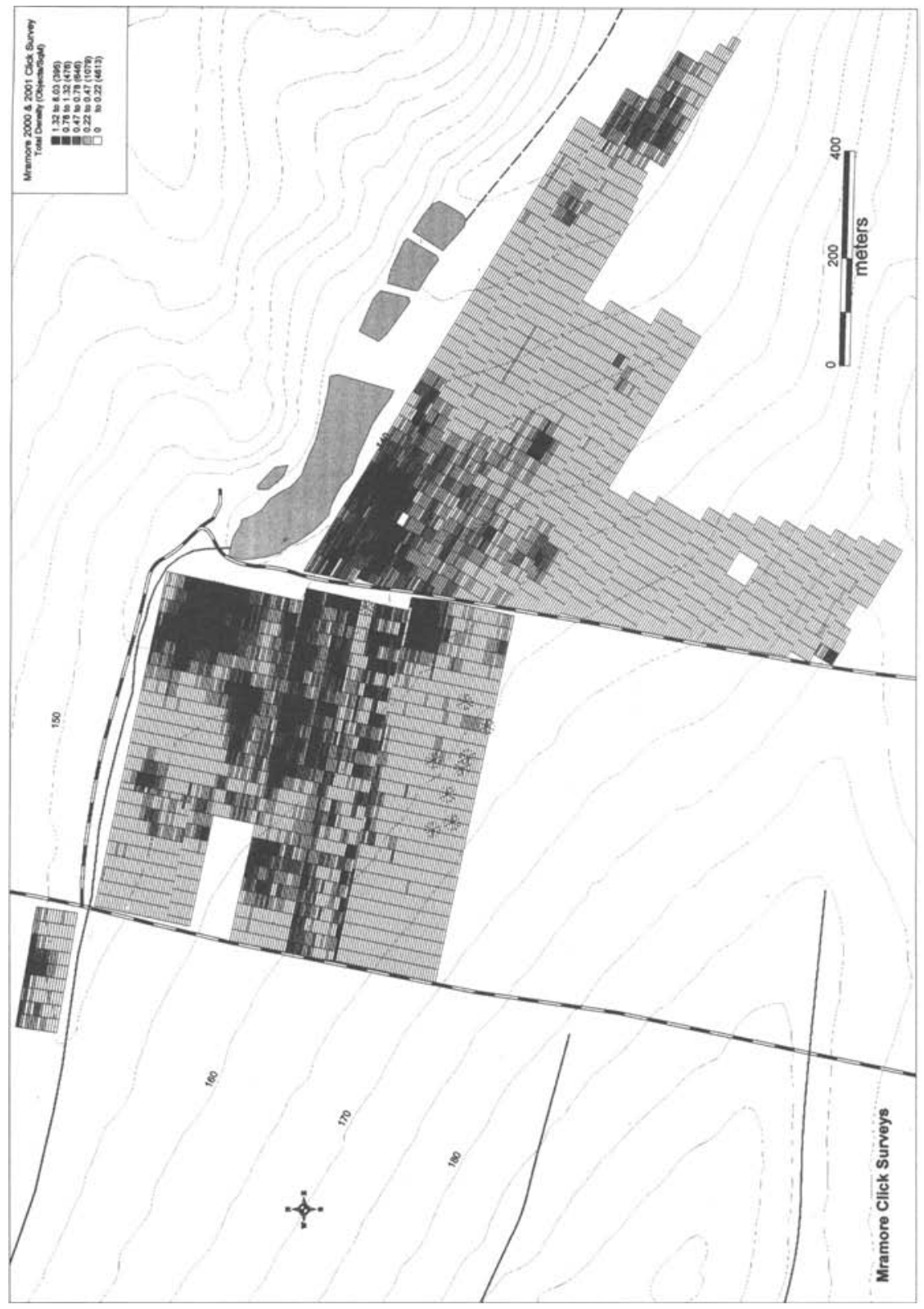


Figure 7. Interpretation of the survey and geophysical results

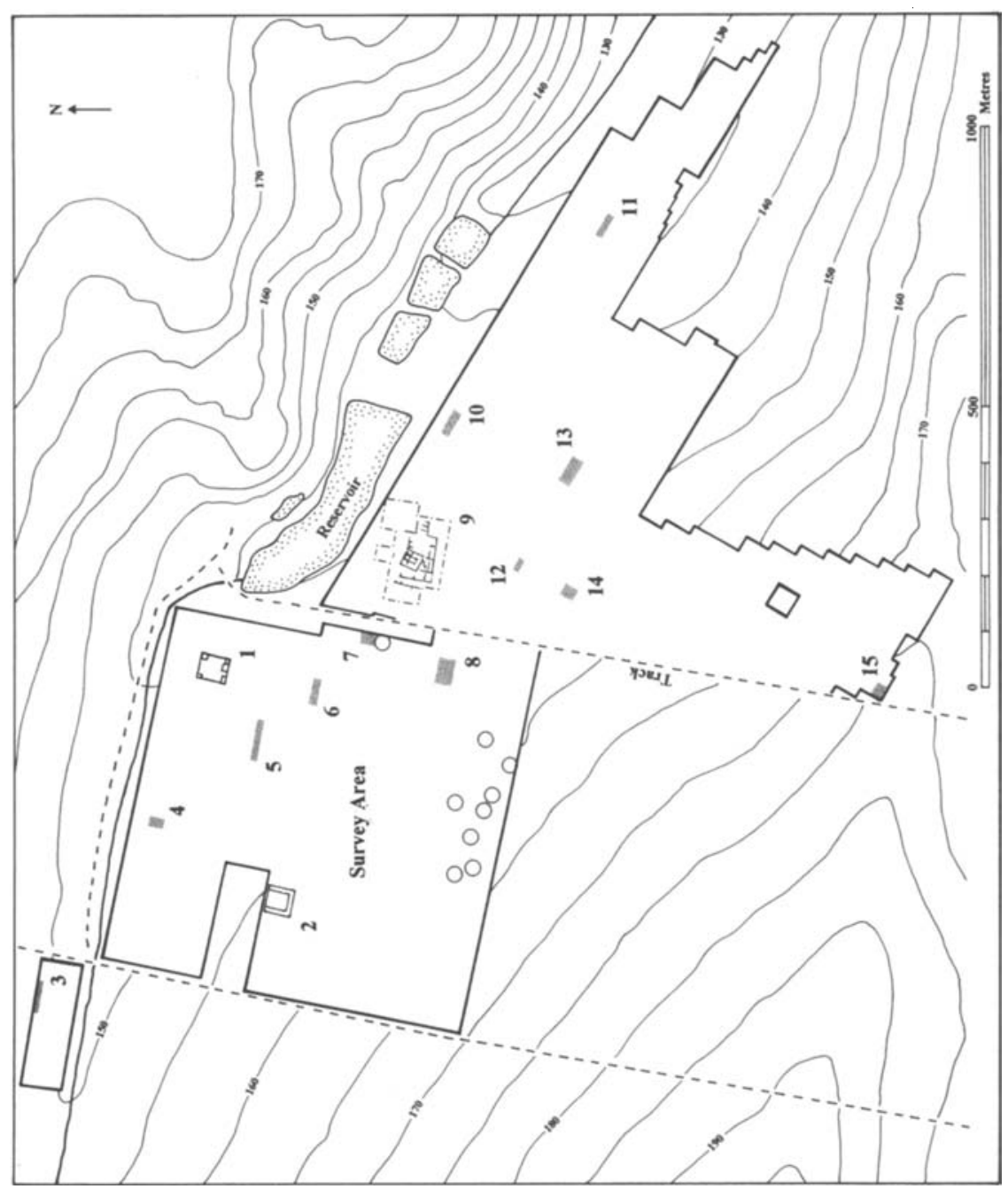

